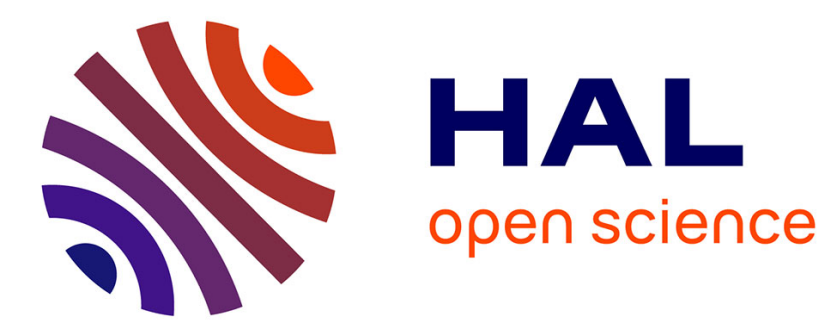

\title{
Adolescents' Scholastic Field, Identity Frames, and Future Projects \\ Jean Guichard
}

\section{To cite this version:}

Jean Guichard. Adolescents' Scholastic Field, Identity Frames, and Future Projects. Jari-Erik Nurmi. Navigating Through Adolescence, European Perspectives, Routledge, pp.279-306, 2001, 9780203823033. 10.4324/9780203823033-11 . hal-03233954

\section{HAL Id: hal-03233954 https://hal-cnam.archives-ouvertes.fr/hal-03233954}

Submitted on 25 May 2021

HAL is a multi-disciplinary open access archive for the deposit and dissemination of scientific research documents, whether they are published or not. The documents may come from teaching and research institutions in France or abroad, or from public or private research centers.
L'archive ouverte pluridisciplinaire HAL, est destinée au dépôt et à la diffusion de documents scientifiques de niveau recherche, publiés ou non, émanant des établissements d'enseignement et de recherche français ou étrangers, des laboratoires publics ou privés. 
To quote this text:

Guichard, J. (2001). Adolescents' scholastic fields, identity frames and forms and future projects. In J. E. Nurmi (Ed.), Navigating through adolescence: European perspectives (pp. 279-306). New York: Routledge Falmer.

RUNNING HEADLINE: Adolescents' Identity Frames and Future Projects

Adolescents' Scholastic Field, Identity Frames and Forms and Future Projects.

\author{
Dr. Jean Guichard
}

Professor of Psychology at the National Conservatory of Arts and Crafts (CNAM)

Director of theNational Institute for the Study of Work and Vocational Guidance (INETOP)

$$
\text { INETOP - CNAM }
$$

41, rue Gay Lussac - 75005 Paris - France

guichard@cnam.fr

KEY WORDS: Adolescence, counselling, field, frame, habitus, identity, school, self, subjectivity, vicariance, vocational guidance. 
Adolescents' Scholastic Field, Identity Frames and Forms and Future Projects.

Introduction: Structures, Interactions, Self-Direction and Future Plans

How are the future plans of adolescents created ? Such a question is typical of our century (though by no means exclusive to it), i.e. for the time in history when emphasis is placed upon the individual (Häyrynen, 1995), ("die Gesellschaft der Individuen", Elias, 1987), Vocational Choice (Parsons, 1909) and "self-concern" (le Souci de soi, Foucault, 1984).

Many theoretical models have been suggested in the past hundred years in attempts to provide answers to these questions. Some of these theories are general, focused on the development of individuals and of their "subjectivity" (e.g. James, 1890 ; Freud, 1917, 1963 ; Jung, 1926, 1960 ; Mead, 1934 ; Wallon, 1934 ; Cattell, 1950 ; Kelly, 1955 ; Rogers, 1961 ; Erikson, 1968 ; Bandura, 1977. "Subjectivity" is used here as a rag-bag word referring to everything covered by the concepts, each in their own theoretical way, of "ego", "self", person", identity", basic personality structure", "habitus, etc.). Other theories, often derived from earlier work, take into consideration essentially the development of individual vocations and occupational choices (e.g.: Ginzberg, Ginsburg, Axelrad \& Herma, 1951 ; Roe, 1956 ; Super, 1957, 1984 ; Gysbers \& Moore, 1973 ; Krumboltz, 1977 ; Gottfredson, 1981 ; Law, 1981 ; Huteau, 1982 ; Vondracek, Lerner \& Schulenberg, 1986 ; Nurmi, 1991).

Whether concerning the development of "subjectivity" or limited to the question of personal and occupational "vocations", these theories lead on to various discussions, one of which is essential. This is the question of the stability or malleability of "subjectivity": does an individual retain the same personal identity, gradually evolve throughout life or, even more malleable, does subjectivity vary according to contexts by which the individual is confronted ?

Without going into the fundamental considerations specific to each notion, it is evident that approaches that put weight to the individual's past at the same time emphasize the relative stability of their subjectivity. This applies to psychoanalysts. They emphasize the role of the conscious and unconscious desires of parents. It also applies to more sociological perspectives: the "basic personality structure" of Abraham Kardiner or the "habitus" of Pierre Bourdieu designate stable constituents of subjectivity. The same goes for certain approaches to the self. 
This stability does not mean immutability. However, stability does imply "resistance to change".

Most psycho-social approaches and some psychological notions are, on the contrary, focused on the dynamics of subjectivity. The basic idea is that events which individuals experience (and some which they anticipate) lead to restructuration of their subjectivity: the structure and self-conception of the individual changes.

Currently dominant trends surmise a dynamic conception of identity processes, though it seems impossible to analyze this dynamics without taking into account the relative stability of the structures of social relations. It is within these structures of varying degrees of stability that individuals enter for certain social games according to the interactions to which they are exposed. In other words, not only structures but also interactions must be taken into account in order to understand the dynamics of identity constructions. It is the role of these two aspects in the development of the future projects of adolescents which is examined here.

This examination first concerns the role of the structure of scholastic organization in the creation of the future goals of young people. The school has taken on a major role in the socialization of young people in developed countries in the 20th century. The fields and habitus theory of Pierre Bourdieu (1984) leads to the following hypothesis: attendance of a scholastic system (organized in a certain way) by adolescents leads to the formation in their mind of a system of representations of themselves, of others, of training and of occupations, organized according to the basic dimensions structuring the system, as perceived by adolescents from the position they occupy in this organization.

However, this analysis leaves two questions unclear. These are, first, analysis of mediations via which these "objective" structures become mental structures and, second, the problem of integration into a relatively unified system of representative "constructs" generated by the various experiences to which young people are exposed. Adolescents are not only pupils, they also live outside school. What cognitive dimensions do they construct as the result of these different categories of activities? How do they combine together? What are the inherent processes of their integration? 
Two hypotheses are offered in answer to these questions. The first is derived from the concepts of symbolic interactionism (Mead, 1934, Becker, 1963) and of dialogic pragmatic philosophy (Bakhtin, 1981, Jacques, 1979). It suggests that all interactions and interlocutions play an essential role in the construction and integration of representative dimensions, which both constitute adolescents' subjectivity and determine the creation of their future representations. Indeed, as Nurmi noted, identity and future representations combine in a dialectic relation: "the ways in which adolescents direct their life have consequences for their self-definition (identity construction), which further direct their subsequent self-direction" (Nurmi, 1997).

The second of these hypotheses arises from a bringing together of sociological models (Dubar, 1992, 1998a \& 1998b) and the concept of frame (Minski, 1975, Barsalou, 1992) as developed in artificial intelligence. This hypothesis leads to the conception of subjectivity as a (relatively) unified and structured system of substitutable "identity forms" in which individuals construct and represent themselves and others. These identity forms are developed from "identity" cognitive frames, i.e. structured patterns relating to categories of people determined by social organization.

This model of frames and vicarious identity forms enables the integration of different approaches relative to "construction of self" and "identity strategies", analysis of the complex processes involved in the creation of future goals in adolescence and questioning of pertinent guidance activities involving today's youths.

\section{Scholastic Field and Future Projects}

In developed societies, school is a basic structure in the socialization of young people. It is an organization, a system, or - to use the terminology of Pierre Bourdieu - a field, i.e. "a collection of social objects having relations of hierarchy and opposition with each other" (Doise, 1990, p.125). Scholastic field is characterized in particular by the "salience" of its organization: its various streams have precise relations between them ; and rules governing its function. 
The component streams of a scholastic field generally differ in terms of prestige: some enable the continuation of longer studies in socially esteemed areas, while others quickly lead to "active life" or to unemployment. In France, educational tracks that are highly valued today are those which emphasize pure sciences, mathematics or classical humanities: the degree of abstraction of studies determines their value at school (or to use Bourdieu's terminology, determines the specific gravity of the scholastic field). Streams differ also according to the types of pupils who have chosen them (or have been selected in them): some streams are mixed according to gender and/or social groups, whereas others tend to attract either boys or girls, young people from advantaged or disadvantaged backgrounds, etc.

Marked differences certainly exist between scholastic systems, concerning how systematically they are organized. All scholastic systems nevertheless function according to rules, some of which are explicit. Others are less clear in the eyes of those concerned - teachers, pupils and parents - who nevertheless heed them. This leads to statements such as "it seems to me that such and such a stream would suit this boy". In Bourdieu's terminology, this indicates that his habitus - i.e. his ways of judging and being - is perceived as being similar to that ordinarily encountered in the stream concerned. It has hence been possible to show the prevalence of a "dominant cultural habitus", i.e. adolescents' relative homogeneity of cultural activities, leisure and interests in a given scholastic stream (Guichard, Devos et al., 1994a; Guichard 1996).

Such an organization of socialization defines the fundamental dimensions in which $\underline{\text { adolescents learn to perceive themselves. School can hence be described as a structured mirror }}$ offering adolescents a certain reflection of themselves in which they recognise themselves in a given way. Seen this way, this structured mirror often becomes a structuring mirror (Guichard, 1993, 1996). Thus, the main dimension organizing vision of self in this mirror is that of excellence as scholastically produced and defined.

Many studies have demonstrated the fundamental role of success or of scholastic failure in the construction of a certain self image. For example, Gilly, Lacour and Meyer (1972) introduced a powerful devaluation mechanism - related to scholastic failure - of own and social images of intelligence, perseverance and attentiveness. Pupils who do poorly at school consider 
themselves (own self image) to be less intelligent, less persevering and less attentive than those who succeed in class. They also feel that others (social self images) judge them in the same way. In addition, Gilly et al. found evidence in these low achieving pupils of disharmony between their own self image and their social self images: they feel that others judge them even more negatively - such as "very dull" - than they judge themselves, e.g. "dull".

Research carried out by sociologists who have looked at the question of the adaptation of young underachievers leaving school (Dubar, 1987 ; Nizet and Hiernaux, 1984 ; Laks, 1983) lead to same conclusions. They showed that these adolescents frequently constructed self images of "men of no quality". Such studies validate the broad lines of Gottfredson's hypothesis (1981) according to which at school, adolescents learn to determine the upper limits of the social positions to which they can reasonably aspire.

This basic dimension of scholastic excellence is not the only one involved in the organization of the scholastic system as a structured mirror. As has already been said, a scholastic system, is always a system of classification of scholastic disciplines going hand in hand with a system of distribution of individuals. This has cognitive consequences: adolescents plunged into a given scholastic system learn in it (implicitly, based upon the organization of a system), first, that certain disciplines tend to go together and that they differ from others, and, second, that these categories of disciplines tend to correspond to types of pupils. For example, in the French scholastic system, pupils learn that modern languages and French tend to go together. They also note that these literary disciplines contrast with scientific disciplines. At the same time, they see that "literary" is concretely associated with "feminine" and "scientific" with "masculine".

Once these objective systems of classification of knowledge and of individuals become cognitive schemes, they play a fundamental role on the representation of the task "making choices for its own future". This was shown at the end of the 1970s by Kokosowski (1983). He noted that future representations of French secondary school pupils formed two sub-schemes. The first refers to the pupil's current scholastic situation. Depending on it, adolescents either appreciate or don't appreciate the school stream in which they are engaged; they feel that they are either strong or weak; they consider themselves doing well, average or poorly in various 
subjects, etc. The second sub-scheme covers, first, constructs enabling the evaluation of higher educational streams (long or short, masculine or feminine, including certain subjects or not, easy or difficult, etc.), and, second, dimensions allowing the representation of occupations (Is-it a sedentary or a mobile job ? Is it relational or office ? Is it conception or execution ? etc.). These dimensions are indeed derived from the present school situation. The weight of current scholastic self vision is hence determinant in representation of the future.

It has been shown more recently that not all the pupils do represent occupations in the same way, but this is connected to the position they occupy in the scholastic system. Notable differences exist in the perception of occupational structure according the gender of pupils, their study stream (Guichard, \& Cassar 1998) and also probably their social and scholastic trajectory (Guichard, Devos et al., 1994a and 1994b ; Guichard, 1996). For example, a boy working for a scientific "baccalauréat" (science related grade) tends to describe doctors and engineers in the same way and to clearly differentiate them from occupations involving helping others. A girl working for a medico-social "baccalauréat" (health service grade) tends, on the contrary, to perceive the occupations of doctor, nurse and schoolteacher as being similar, and to differentiate them from engineer.

These findings are contradictory to Gottfredson's (1981) hypothesis of a single cognitive map of occupations: although all adolescents emphasize the dimensions "prestige" and "masculinity-feminity" in their evaluation of occupations (as postulated by Gottfredson), this does not imply that they refer to a given cognitive map describing the occupational structure. On the contrary, the structure of relations between occupations appears to be determined by the position occupied by the adolescent in the educational system.

Consequently, it looks as if the scholastic system provides a basis for shaping not only the self image of pupils but also the way in which they project themselves into the future. The scholastic self reflection formed in the structured mirror is hence a powerful stimulant to the "creation of vocations".

But how and when do pupils recognize themselves in this reflection? How do they internalize this self image offered by school? How does the structured mirror become a structuring mirror? Or, as was asked by Sartre (1952, p.56) about Jean Genet: how and when 
does the person to whom one says: "I see you as a thief", then say to himself "I'll become the thief that you see in me".

\section{Social Cosmos, Interactions, Dialogue and Subjectivity}

Structural Homologies

Pierre Bourdieu's model provides a useful approach to the understanding of this self recognition. According to his theory, highly differentiated societies are made up of a collection of "relatively autonomous social microcosms" (Bourdieu \& Wacquant, 1992, p. 73), i.e. of fields, of which the scholastic system is a prototype example. Relations between the elements of a field are always "evaluative"; but what determines value (the "specific gravity") in a given field is different to the one in an other. For example, "the artistic field, religious field or economic field obey different logics" (Bourdieu, Wacquant, 1992, p. 73). These fields are nevertheless organized in an analogous manner: relations between positions of individuals in these fields are generally homologous.

To educate an individual is to plunge him/her into a plurality of fields. This immersion is necessarily located at a given point in each field. This has a major consequence: individuals learn to perceive the entire field, i.e. the elements making it up, and the relations of its elements, from the individual's viewpoint. This viewpoint of the field which is produced from experiences - practices - related to this particular position in the field, is a constituent of the habitus of the individual. For example, an individual who, as a child, went see with his/her parents many exhibitions of contemporary art may have built in his/her mind a system of classification of paintings that values all forms of abstractionism. Hence, for such an individual, one of the fundamental dimensions of evaluation in this field of art would be: how much any work renews the way the material is worked? S/he would then tend to organize all the works of art (and also the people interested in them) particularly along this dimension (and would make a clear distinction between the "pompous" painting of the end of the 19th century - seen as common or vulgar - and impressionism, seen as an important step towards abstractionism). Another individual, whose experiences in this field were completely different from the previous one, may have built in his/her mind a completely different system of classification of paintings. 
For him/her, one fundamental question to judge any work could be: how well is nature depicted? In such a case, all the kinds of paintings of the end of the 19th century would be seen as relatively similar and totally different from works by Poliakoff, Pollock, Rothko, etc. (which probably would be rejected as: "stains, that a child could do").

$\underline{\text { Habitus consists of a certain number of schemes of perception, assessment and action }}$ which continue to provide guidance in the individual's representations, judgments and acts long after the period of its creation. Social position in each field is therefore fundamental: it determines the nature of learning experiences, which themselves lead to the creation of systems of classification and perception (and practices).

This model raises the hypothesis according to which the more similar are the positions occupied by adolescents in the various fields they are involved, the more they will immediately recognize themselves in the scholastic self reflection. Hence the middle-class boy, living in a middle class area, good pupil in a scientific stream, will be ready to see himself as being endowed with abstract intelligence. Reciprocally, a girl of modest origins, living in a working class suburb, having difficulty working for an administrative diploma, can easily see herself as tending more to have good practical sense. The situation is more complex in cases of positional disharmony $^{(1)}$. Taking as a background the findings of Howard Becker $(1963,1985)$ in the constitution of deviant identities, it can nevertheless be suggested that interactions with others then play a fundamental role. In a more directly dialogic perspective, it can even be postulated that "I" is defined, redefined and constructed via the mediation of discussion with others. Dialogic interaction would then play a fundamental role in the construction of self. In the dialogic interaction with others, "I" recognize myself and hence construct myself.

\footnotetext{
${ }^{(1)}$ Disharmony of positions in different fields marks representations of occupations. The study mentioned earlier (Guichard et al., 1994) evaluated in particular the "cognitive maps" of occupations of certain adolescents in contrasting positions in different fields (e.g.: secondary school pupils in a prestigious stream, but with "popular" cultural habits, distinguishing them from the great majority of their co-pupils, or apprentice mechanics whose "distinguished" cultural habits differentiate them for other apprentices). Such individuals are very much in the minority. It is therefore difficult to draw firm conclusions from these findings. Nevertheless, the cognitive maps of occupations of these adolescents invariably differ from those of their companions. For example, secondary school pupils with a privileged position in the scholastic system but with popular cultural habits represent prestigious occupations in the way of youngsters with popular tastes (differentiating them from their class companions) while they perceive less prestigious occupations in the same way as their companions.
} 


\section{Relational Transaction and Biographic Transaction}

In his approach to identity construction, Claude Dubar (1992, 1998a) draws a distinction between two types of process: a biographic transaction and a relational transaction. The $\underline{\text { biographic (or subjective) transaction consists of relating inherited identities and targeted }}$ identities, of "the projection of possible futures in continuity or break with a reconstituted past (trajectory)" (Dubar, 1992, p. 520). The relational (or objective) transaction is a process of relating attributed or proposed identities and assumed or incorporated identities. It involves "ensuring recognition or not by institutional partners of the legitimacy of one's expectations, taking into account goals and means ("policy") of the institution" (Dubar, 1992, p. 520). "The biographic, temporal and "subjective" dimension brings into play the continuity of social origins and the direction of individual trajectories ; the purpose of the relational, spatial and "objective" dimension is the recognition of claimed positions and the success of structural policies. Interconnected by necessity, the two transactions are in an interaction relation: the outcome of each depends upon the other" (Dubar, 1992 p. 521). The biographic transaction could hence be said diachronic and the relational transaction to be synchronic. Identity construction would hence be the fruit of a double transaction: a negotiation relative to institutional identity offer and an intimate deliberation (1998b).

This model can be translated into the language of the self psychology. The relational transaction refers to the problem of articulation between social images of self and own images of self. The biographic transaction designates the question of links between past self, current

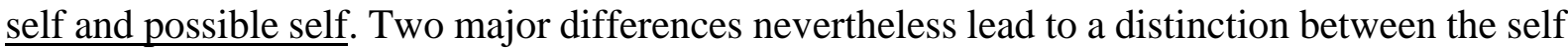
psychology and Dubar's model.

Dubar emphasizes the role of social labeling and of what he calls identity offer, i.e. proposed identities in which individuals can recognize themselves or not. This labeling and this offer are one of the origins of identity forms. These forms, in which individuals identify themselves at least momentarily, are defined as "unstable products of these biographic and relational transactions in a context of powerful instigations to change" (Dubar, 1998b, p. 100). 
Dubar also emphasizes the role of "narrative", the role of argumentation about self, in the genesis of these identity forms.

This interesting model of Dubar needs to be more precisely defined for the psychologist. In particular, the role of narrative in the construction of self and the notion of identity form must be analyzed and clarified.

Forms of Interlocutions and Identity Forms

A narrative is always intended for someone. This can be an actual other. This other person can also be an internalized other: another within oneself. The narrative is for others. In every instance, the narrative refers to a dialogue: it is what the individual intend to say to the person to whom s/he is talking. The narrative presupposes somebody else who is addressed in answer to a question, an assertion, a sign, etc., perceived or imagined by them. Dialogic interaction is the very principle of narrative.

This other (empirical actual or imaginary) to whom the individual addresses him/herself depends upon by current or past interactions. S/he enters into dialogue with a person - or s/he constructs this narrative for people - with whom s/he has or has had certain relations. The community interactions evoked by Bill Law (1981) or the micro-systems of Vondracek et al. (1986) hence appear to play crucial roles in the construction of self. It can be surmised that during these actual or imaginary dialogic interactions - or during these narratives - a given possible self appears to the individual as a probable self while other possible selves become improbable.

Dialogic interaction is certainly not the only factor involved in this move from a possible self to a probable self: the actual experiences of individuals (and notably their activities, successes and failures, encounters etc.), combined with the way in which they are represented, play a major role. It may, however, be surmised that in order to internalize these experiences and representations their own, individuals must tell themselves (or others) about them, interaction with others then playing an essential role.

The distinction drawn by Dubar between synchronic process and diachronic process is heuristic. However, the biographic (diachronic) transaction cannot be analyzed as a simple 
intimate deliberation. This very deliberation is dialogic in essence. It can be postulated that is precisely the recounting of self for others that enables this move from identity offer to self-identification in this specific identity form. As noted by Francis Jacques (1979, p. 384) (in an ontological perspective): "In fact the question is not so much to know whether the "me" is defined only in relation to another, but to know whether the relation with the other really helps in defining oneself (...). "You", is the other as its enters "me" in a community of communication (...). The first philosophical fact is that of exchanged speech circulating between themselves in their created space". "Each hears himself in the other, just as the other speaks in himself", stresses Jacques (1979, p. 385).

But Bakhtin (1981) would add, this other speaking within us, speaks in determined forms. These voices (to use Bakhtin's terminology) of others in us use national languages. They are made up of types of social speech (e.g. occupational jargon) and sorts of speech (e.g. table conversation). My voice - i.e. my uttered statement, for that intention, with this tone and that accent - is based upon the appropriation ("ventriloquism") of the voices of other people in other contexts. "The word in language is half someone else's. It becomes "one's own" only when the speaker populates it with his own intention, his own accent, when he appropriates the word, adapting it to his own semantic and expressive intention. Prior to this moment of appropriation, the word does not exist in a neutral and impersonal language (it is not, after all, out of a dictionary that the speaker gets its words!), but rather it exists in other people's mouths, in other people's contexts, serving other people's intentions; it is from there that one must take the word and make it one's own. (Bakhtin, 1981, pp. 293-294, cited by Wertsch, 1990, p. 117).

Our own language is thus constructed in the social forms of speech, in what could be called, to use the terminology of Schank and Abelson (1977) "scripts" but scripts varying according to the social contexts frequented by the individual. It therefore seems possible to propose the following conclusive hypothesis: socially determined forms of interlocutions (see Erving Goffman, 1974) seem to be an essential factor in the construction of self in a determined identity form (i.e. in the appropriation of a given identity offer).

In adolescence, these forms of interactions and interlocutions - notably with pairs could play an essential role in the trials of identity forms which some authors consider to be 
characteristic of this period (see adolescence as psycho-social moratorium of Erikson, and the period of tentative choices of Ginzberg et al., 1951). It is possible, for example, that the "inner voices" produced in each participant by the types of socialized speech used by a group of young rappers create the image of a dynamic, impulsive, or even violent, personality. By the appropriation of this "voice", during these interlocutions, via ventriloquism of this voice, adolescents could construct themselves in this determined identity form of "rapper". (In a way, this comes down to the idea of learning by imitation; but what is imitated is the "voice", i.e. language, tone, intention, type of social speech and sort of speech of others).

Frames and vicarious identity forms

The concept of "identity form" is ambiguous to the psychologist. This terminology suggests the existence of underlying and relatively integrated dimensions. But what are these dimensions? How are they integrated? How to conceive the relative instability of the identity which the concept of identity form attempts to grasp? These various questions lead to an essential query for the psychologist: what is the nature of the mental representations involved?

In psychology, the concept semantically closest to that of form is that of frame. This was defined by Minsky in 1975, in the field of artificial intelligence. Frame designates a mental pattern relative to the structure of a familiar situation or object. This mental structure incorporates slots which have generally some default values (Barsalou, 1992, p. 160). For example, the "room" frame incorporates the features "walls", "floor", "ceiling", "door" and "window". These features have defined relations with each other. According to this cognitive perspective, our mind is made up notably of a system of frames. To understand information or a situation or recognize an object is to determine the frame or configuration of frames which best enable it to be grasped.

\section{Identity frames}

The cognitive frame is not a representation immediately present in consciousness. It is a structure which enables individuals to immediately grasp an "object" (actual, social, a situation, etc.) in the world around them. The following definition can be proposed in this context: an 
identity frame is a structured (cognitive) scheme relative to the main characteristics of individuals belonging to one of the categories of people which our social experience leads us to identify. Examples include: woman, catholic, "gay", Ford worker, football team supporter, Scorpio star sign, truck driver, German, immigrant, etc. The particular characteristics which the identity frame takes into account are: physical traits, "psychological" traits (character, temperament, skills, etc.), ways of presenting oneself, of behaving, interacting, speaking, acting, etc. Some of these characteristics have defined relations with each other: for example, certain factors are immediately perceptible while others depend upon the interior nature of the person, and perceptible factors may be indicative of character traits.

The identity frames system

Identity frames are cognitive (not immediately conscious) representations enabling the situation of others and the situation of oneself in relation to others. Some of these frames are more general than others, or are formed earlier, or more central, or more universal perhaps; some are prestigious, some designate minorities, some refer to stigmatized social groups, etc. Identity frames form a system in the mind of those using them as representation. The identity frames system designates the structured entity of relations between identity frames, in the mind of a socially situated individual. These relations may be inclusions, exclusions, or complementarities. They often involve evaluations, notably in terms of prestige and legitimacy.

The identity frames system is the substratum of representation of the structure of relations between social categories ("social groups" of all types) as organized in the mind of an individual objectively and subjectively situated in his or her "social cosmos". It is the identity frames system which organizes the vision of relations between "social groups" of an individual. The identity frames system is the identity offer in our mind.

Identity forms

The identity frames system is a structure of structures underlying the representation of self and of others and the construction of self. In such a perspective, identity form is a conscious 
representation of self (or of a determined other) according to the structure of a defined identity frame.

Results of research on identity and groups, however, lead to the identification, among identity forms, of subjective identity forms. These do not simply involve an activation in working memory of identity frames in which individuals would recognize themselves. Whereas some stereotyped dimensions can enable the representation of others in a defined identity frame, subjective identity form is a veritable construction of self in an identity frame, bringing into play the phenomenon of "identisation" (individuation) (Tap, 1980), of "primus inter pares" (first among equals) (Codol, 1975) and of "subjectivisation" (Foucault, 1983, 1994-IV). From a cognitive standpoint, this means that individuals assign specific values to certain slots of the frame when they construct themselves in a form corresponding to this frame.

The Construction of Vocational Identity Forms in Adolescence

One of the "developmental tasks" (Havighurst, 1953) which our societies demand of adolescents is that they construct representations of self in certain subjective identity forms corresponding to jobs "which would suit them". In the early 50s, Ginzberg et al. (1951) described the stages in this process as they were able to observe in American boys from a privileged background. More recently, Dumora (1990) observed the evolution of the construction of such vocational identity forms in adolescents from various social backgrounds, aged between 11 and 16, whom she monitored for four years. She identified four phases in this construction.

The first is a tautological link between self and a given occupation. It is not so much the job as the person doing it which arouses the dreams of the pre-adolescent. This link is described as "tautological" insofar as there is no argument as its basis: no characteristic, of the job incumbent nor job, is mentioned. A girl who "sees herself" as a model hence says: "model? (laughs).. well (laughs) I don't know, I like that, it's like this... when you like something, it's because it's what you enjoy..." (Dumora, 1990, p. 113).

The second phase is that of a "metaphoric projection": between the individual and the person doing the job, there is transfer of an entity to the other, without possible recognition of a 
shared characteristics, hence of a descriptive category, of a feature linking the current status of the one with the anticipation of the other". "Syncretically, there is a single edifice, with the subject identifying themself with the person or character: "oh, it's because I would really enjoy that, I just dream about it, .. I can already imagine myself.. just as if it was now.. as if I was already there.. I can imagine myself with lots of animals around me to keep me busy" " (Dumora, 1990, p. 115).

This is followed by the time of a "metonymic projection". "Projection because it refers to a character or known person, but with the beginnings already of separation from the character so as to retain only qualities or characteristics, and metonymic because there is (...) an intersection between the various characteristics of the subject and the various characteristics of the professional". For example, a girl about fifteen years old says "secretary, there like Mrs. M. at school, it's because you have files, the telephone to answer, people to see... since I enjoy contact with others... me, I'm quite an obsessional type (..) but that doesn't make me difficult on the telephone..., ... so" (Dumora, 1990, pp.115-116). This is certainly still a projection ("like Mrs. M."), but descriptors relative to actions seen are now brought into correspondence with the qualities perceived as being necessary for the job.

The final phase in the construction of these vocational identity forms consists of "tensional comparisons". Reference to the person doing the job is no longer necessary: "The metonymic process no longer functions by reference to an individual mentioned but already to the impersonal image of a professional (...). The subject sheds identificatory investment, to opt for the cognitive construction of the professional image and hence put it at a distance. A girl about 15 years' old hesitating between doctor and teacher argues as follows: "since I like contacts, talking to younger or older people, and I also like long and difficult studies preferably (laughter).. not short things... since I want to succeed in life, it's important... oh, it's difficult to to say... (...) I am hesitating because I want a good job but I want to do studies well... for example medicine (...) that's a job which I would enjoy.. the job and not the studies..."" (Dumora, 1990, p. 117).

Progress from tautological links to tensional comparisons is hence "a cognitive detachment of identification by the designation of resemblance, then by a classification of 
categories emerging from this identification support and finally by logical implication" (Dumora, 1990, p. 117). These observations cover the description of creation, in adolescents at school, of relational transaction processes - reported by Dubar (1992) - relative to the anticipation of vocational subjective identity forms.

The second process described by Dumora is an equivalent, in the school field, of Dubar's (1992) biographic transactions. This involves a "probabilistic reflection" consisting of "a subjective calculation in which the subject takes the measure between the space of possibles and the space of probables" (Dumora, 1990, p. 118). Dumora notes that from entry to leaving junior high school, this reflection evolves "from prediction (positive or negative quasi-absolute certainty), to conjecture (uncertainty) and finally to a reasoned and ordered strategy of possibles" (Dumora, 1990, p. 118).

\section{Double Vicariance of Identity Forms}

While vocational subjective identity forms play an important role in the construction of self, they are nevertheless not the only identity forms in which subjects construct themselves.

The construction of self (in any particular subjective identity form) depends upon the relatively stable characteristics of the person (recognizing themself according to these dimensions of those particular identity frames) and contexts of actualization of self. It seems necessary to return to the analyses of Michel Foucault (extending old debates in psychology, notably between Thorndike and Eysenck). Foucault (1984, 1994-IV, p. 719) states that the subject "is not a substance. It is a form, and this form is not always the same. You do not have with yourself the same type of relation when you take yourself to be a political subject who is going to vote or when you seek to fulfill your desires in a sexual relation. There are doubtless relations and interferences between these different forms of the subject, but the same type of subject is not present. In each instance, one plays, one establishes different forms of relation with oneself".

The notion of "vicarious processes" suggested by Reuchlin $(1978,1997)$ leads to proposition of the hypothesis of a double vicariance of identity forms. In a given context, the subject constitutes themself in a particular identity form (e.g.: supporter of "Paris-Saint 
Germain" football club). This construction of self in this identity context would be in an identity form characteristic of the individual concerned: a subjective identity form (where the slots of the frame have their own specific values). In another context, this same individual could construct themself in another subjective identity form (e.g.: "Ford worker"). This would be the first vicariance of identity forms. The second would involve variations in the construction of a given subjective identity form related to the context of actualization. The "specific" value assigned to one or other slot of the frame would be subject to certain variations. For example, the "behavior" characteristic of the "Paris-Saint-Germain supporter" identity frame could take the specific value "violent to others" in a given individual. This value would be that of the behavior "slot" of its subjective identity form. This, in the context of a particular match, could lead to self constitution in an actualized subjective identity form of a verbally violent individual, and in another, a physically violent individual.

Identity Forms System and Subjectivity

This double vicariance of identity forms does not lead to disappearance of the unity of the individual. Feelings of being the same and that others are the same are very strong. These two types of representation are based upon the unity of the identity frames system. The feeling of being the same is based upon the feeling that the different personal identity forms in which we identify ourselves go together, that they are all mine. They form for individuals the $\underline{\text { subjective system of their (subjective) identity forms. Subjectivity is hence the unified and }}$ structure system of the identity forms in which individuals construct and represent themselves. This is the conscious representation of relations between subjective identity forms. This representation can obviously evolve. It is also sensitive to social contexts: in a very structured social organization, in which social relations between individuals are at one and the same time simple, clear and salient, the feeling of being the same, of always being identical to oneself, is much stronger than in a society where individuals may construct themselves in different identity frames.

Scope of The Frames and Vicarious Identity Forms Model 
The advantage of the model just described in terms of its broad lines is to enable integration of different current approaches of "subjectivity" in cognitive psychology and in sociology. The concepts of identity frames and forms, vicariance and identity forms system allows to relate the problematics of psycho-social identity, self-schemata, implicit theories of personality, the "ego ecology of identity words", identity strategies, etc. Being unable to examine all these problematics here, only two of them will be considered: those of "self-schemata", and of "identity strategies". These approaches appear to be particularly pertinent in analysis of the construction of future projects of adolescents.

The "identity frames" in which individuals construct themselves in a certain form echo self-schemata of the self psychology. This notion of identity frames nevertheless adds not only cognitive (concerning the structure of these schemata) but social considerations. In the self psychology, "social" is generally limited to taking into account local interactions with others, as if they took place in a social vacuum, independently of local structures (i.e. fields) as well as of the social cosmos. In the model proposed here, the central dimensions of self involve the representation of the structure of relations between groups of individuals.

This model of the double vicariance of identity forms also enables analysis of identity changes and strategies. These can be conceived as being notably determined by contextualized actualizations of identity forms. The subjective identity form of an individual in a given identity frame would be the product of the different contextualized actualizations in this form. These actualization would be the source of its evolution. Inter-individual interactions would hence play a major role, leading to "day by day adjustments, brought about according to variations in situations and their consequences - i.e. finalities expressed by social actors - and their resources" (Taboada-Leonetti, 1990).

The role of socially esteemed identity frames in these individual (and inter-individual) strategies cannot be ignored. They can be considered to be at the origin of forms of idealized self and of forms of possible selves: these forms being related to certain social insertions (to positions) in determined social contexts (in fields).

In contrast to the canonic model of identity strategies (Camilleri et al., 1990), the considerations of Michel Foucault concerning power and "governmentality" are actually taken 
into account in the model presented here. It is known that Foucault (1988) considers "technologies of the self" to be techniques of power. They designate "procedures which or proposed or prescribed to individuals to determine their identity, maintain it or transform it according to a number of ends, by virtue of relations of mastery of self over self or knowledge of self by self" (Foucault, 1981, 1994-IV, p. 213). In Foucault's conception, subjectivity forms in which individuals recognize themselves are the product of strategic relations of power between groups or between individuals, with as their consequence the government of each individual through his/her relations to others. The maintenance of social order requires the recognition - by each - of self and of others in these forms. In other words, questions of the identity of individuals or of the anticipation of self in "possible selves" are not of a strictly personal or inter-individual nature. They involve, in essence, social organization as a whole and the power relations which ensure its cohesion.

\section{Identity Forms and Adolescent Goals}

Only the undertaking of a systematic program of empirical studies would enable validation of the frames and vicarious identity forms model. This could involve identification of the various identity frames in which, for example, secondary school pupils constitute themselves in defined identity forms. It would also look at the structure of each of these frames and the system which they form. It would also need to confirm the role of inter-individual interactions in the construction of self in certain identity forms.

Although such a research program is as yet only at the stage of a preliminary outline, various empirical studies can be considered as providing indirect confirmation of some of the hypotheses proposed. Three will be mentioned. Two concern the role of effective interactions in the construction of self. The third more precisely concerns identity strategies.

\section{Interactions and Subjectivity}

The question of the role of interactions in the formation of a self image was considered in particular by Meyer in 1986-1987 in a new look at the work cited earlier of Gilly, Lacour and Meyer (1972). The fundamental intention in 1986 was the same as that of 1972: to describe the 
link between scholastic results and the way adolescents perceive themselves. However, on this second occasion, mediating variables were taken into account. These include the interest shown by the family in the adolescent's school work. Such an interest involves family dialogue about school work. The results showed that good pupils had a more positive scholastic self image than the weak. However, this image was also more positive, among both good and weak pupils, when parents discuss these matter. Such a result is of capital importance from a pedagogic standpoint: it is known that self image as a good or weak pupil is not merely a product of scholastic results. This image plays a role in the production of school performance: it produces a certain cognitive function (Monteil, 1988, 1990).

\section{Dialogue and Self Image}

Another research project (Guichard \& Falbierski, 1994; Guichard \& Dosnon, 1999) more directly manifests the role of dialogue interactions in the formation of certain self images. This research was also inspired, in part, from the problematic of Gilly, Lacour and Meyer. The participants were young people (mean age: 17) leaving school having failed, unemployed and in precarious social conditions. Two equivalent groups (experimental and control) of 12 young people were created. Each answered at a five week interval two questionnaires (using Likert's scales in particular) concerning their own and social self images, skills, representations of occupations, etc.

During the five weeks, the experimental group participated in a Careers Education program (DAPPI, see Guichard, 1989 \& 1992) lasting four half-days. The objectives of such sessions were as follows: to help these adolescents to enhance their self image and overcome when applicable - their feelings of desperation, to lead them to establish a link between personal skills and vocational qualifications and to discover ways of acquiring skills other than by learning at school.

DAPPI educational method is based upon two basic principles: the avoidance of cognitively costly transfer operations and encouragement of verbal exchanges. In order to meet the first of these requirements, the DAPPI program limits itself strictly to the question of vocational assignment. Material has been constructed on the basis of interviews with 
employees doing jobs accessible to the youngsters in question. In order to enhance exchanges and dialogue, "DAPPI" consists of several games exercises, where the aim is to reach a satisfactory solution by coming to an agreement with one's peers. Participants often find themselves in situations analogous to those of socio-cognitive conflicts: they have to negotiate to reach an agreement.

"DAPPI" consists of three basic stages. During each of them, participants are divided into sub-groups of 3. The first is aimed at leading participants to discover that their vision of occupations is limited and simplified. Each group of 3 participants is given a pack of about sixty cards, showing the description of a task forming part of an occupation. For example: "I reserve the director's airline tickets. I also telephone to make his appointments". The adolescents are told how these cards have been written following interviews with professionals who described everything they do during their working days. Participants (1) have to discover how many occupations are covered by the sixty cards they are holding and (2) to reconstitute these occupations, i.e. to reconstruct the descriptions of the working days of each of these job incumbents.

Packs distributed to each group are actually based upon interviews with 3 job incumbents. Following this first game, participants generally reach the following 3 main conclusions: (1) a job covers far more activities than they had imagined, (2) different jobs include identical activities and (3) certain positions, which they thought they knew, are very different to the image they had had of them.

The second stage is intended to lead the youngsters (1) to focus on the link between personal skills and vocational qualifications and (2) to discover various means for the acquisition or development of skills. The same small groups of 3 youngsters are given a new pack of about 50 cards. Each card describes an experience (positive or negative) which, in the eyes of a job incumbent, has played a role in his or her vocational career. These experiences are reported by the same three professionals whose job the adolescents discovered during the first game. They must now reconstitute the life itineraries of each of them. Following this second game, participants often draw two conclusions: (1) most trajectories are non-linear and there is not always a link between diplomas and jobs done, and (2) skills are acquired during various 
life experiences: collective responsibilities, training schemes, little jobs, leisure activities, sports, etc.

The third phase involves the transfer to self of findings discovered during the two previous stages. It consists itself of three phases. First, each participation chooses, with the help of the others, vocational activities - tasks - which he or she would like to find in their future job. The aim is to force the adolescent to enter into a process of thought about their vocational future, not in terms of jobs (so as to avoid difficulties related to the stereotyped nature of their representation), but based upon the activities they would like to find in any future job. Each participant then makes a sort of personal "evaluation", based upon an inventory of their skills, knowledge, strong points, etc. Each then defines a plan of personal activities to be taken up in order to acquire or develop the skills required in vocational activities which interest them. Interactions with the other 2 members of the small group are essential at this point. It is they who actually suggest these activities to the adolescent concerned.

The results of this study are clear-cut. Descriptions of self of youngsters in the experimental group were much more positive in the second questionnaire than in the first one (there was no notable variation in the control group). As an example, results related to two questions taken from Gilly, Lacour and Meyer (1972) will be presented. (For presentation of all findings, see Guichard \& Falbierski, 1994).

The adolescent was confronted with a series of descriptors (social openness, intelligence, memory, frankness, independence, perseverance, politeness, quickness, organization, beauty, strength, experience, enthusiasm, foresight). S/He was first ("own self-image") asked what score s/he would give to each of them (scores ranging from 1: $\underline{\mathrm{I} a \mathrm{~m}}$ not at all like that to 7: that's just like me). S/He was then ("social self-images") to say what scores s/he imagined his/her co-participants, the educator, etc., would give him/her on the same grading system.

Table 1 ("own self-image") clearly shows the increase in mean scores assigned by participants. This progression affected above all those descriptors referring to social qualities (social openness, foresight, experience, frankness, politeness, etc.). 
Insert Table 1 about here

The greatest change concerned the social self-image "educator", i.e. the scores which the adolescent imagined that the educator would give him/her (Table 2). They increased by more than one point on average in the experimental group, while there was no change in the control group.

Insert Table 2 about here

The model sketched here suggests the following interpretation of these observations: variations seen in the experimental group could reflect changes - in the personal identity form of each - resulting from the dialogue-based activities of the program. Unfortunately, the experimental device did not offer the possibility of confirming whether these changes were durable: several questions would have been needed to ensure the stability of these variations. (It may be mentioned that the methodology used presupposed that individuals perceived themselves in the identity frame imposed upon them by the questionnaire).

\section{Anticipated Identity Forms}

The studies of Paul Willis $(1977,1978)$ in the Midlands in the late seventies appear to be fully consistent with the conceptual frame proposed here. Willis observed the transition from school to active life of adolescents - underachievers - whose fathers worked in the heavy metal industry. He depicted ways of being, talking, interacting with others, values, certain social representations, etc., of these youngsters and their fathers. This led Willis to describe to what he calls, on the one hand, an counter-school culture, and on the other hand, a shop-floor culture. These two cultures proved to be very similar. For example, on the shop-floor, the fathers of these adolescents distributed tasks between them without paying attention to the instructions of their supervisors. Similarly, at school, the youngsters organized disturbances aimed at disorganizing timetables. On the shop-floor, as at school, the representation of self and of others was structured according to a fundamental opposition between "us" ("lads", "those in on 
things", forming part of the group) and "them" ("ears'holes", "those who want to succeed", the others).

Willis' main conclusion is that the counter-school culture provides adolescents with active preparation for entry into the world of the shop-floor. It can be considered as showing processes of construction of self in a current identity form anticipating a probable and esteemed personal identity form. These processes could be as follows. The organization of production and work in the steel industry determined a powerful identity frame enabling steelworkers to develop a representation of themselves in powerfully structured personal identity forms, particularly stable and esteemed in their eyes. Via family stories about shop-floor life, the sons of these steelworkers developed very precise self representations in this identity frame.

The counter-school culture also seems to be a sort of game in which youngsters learn in anticipation their ways of doing, being, talking, etc., making up the personal identity form which will be theirs a few months later in the "steelworker" identity frame. It can therefore be considered that these games of the counter-school culture are collective identity strategies (Camilleri et al., 1990). They lead these adolescents to anticipate a social position which will be theirs several years later. Actively constructing themselves in these particular identity forms, these youngsters - in agreement with Foucault's hypothesis - accept their lot: they participate in the maintenance of the structure of power relations between social groups.

\section{Conclusion: Adolescence, Subjectivity and Society}

Previously presented findings and hypotheses can be summarized as three propositions. The first concerns the weight of scholastic organization in the construction of some dimensions of self images of adolescents, dimensions which are fundamental in the formation of their future goals. This organization structures in particular the way in which the task - "making choices about my future" - is represented. The second stresses the role of interactions and dialogues with others in the construction of adolescents' self-images and goals. It emphasizes that these interactions and dialogues take place in social contexts and frames (in the sense of Erving Goffman). The third proposition considers that any society determines an "identity offer" which is organized in a person's mind in the form of a system of identity (cognitive) 
frames. In a given context and at a given time, an individual constructs him/herself in a determined subjective identity form. Hence these identity forms appear to be susceptible to vicariance.

This model corresponds to a conception of relatively malleable subjectivity. More precisely, the "stability" or "malleability" of self depend fundamentally upon the development of the particular society (the degree of diversification of identity offer varies according to societies), the degree of integration of the various domains of the social cosmos (and, hence, of different identity frames) and the variety of contextualized interactions in which the subject becomes involved.

In our complex (and democratic) societies, where different fields have their "own logic", adolescence (and also young adulthood) are phases during which young people try out transitory identity forms. These experiments enable them to hasten the construction of their subjective systems of identity forms (the evolution of which is often slower afterwards). Transitory formations and the diversity of juvenile subcultures would hence provide the means for this construction. There are two known dangers which, according to Erikson and Marcia, then threaten the adolescent: identity confusion, and forclosure. In the model sketched here, the first designates inability to recognize oneself in a stable manner in a subjective system of identity forms. The second refers to incarceration in a few identity forms, incarceration which may be related to family pressures or due to more directly political events (such as inter-ethnic conflicts).

These considerations certainly have consequences with regard to vocational guidance methods. They lead to definition of a first line of demarcation between them. The aim of some of these methods is to lead adolescents to stabilize themselves in a determined identity form. Others may pursue the opposite aim.

Counseling activities aimed at helping the client to reach a decision belong to the first type of intervention technique. Reaching a decision implies accepting to construct oneself in one or several determined identity forms. It implies to make progressively this (or these) form(s) into one (or some) subjective identity forms(s) ("this is how I see myself in the future"). 
Counseling activities aimed at helping clients to commit to a transition process pursue the opposite objective. This may involve helping the person to "renounce" certain identity forms: this is often what is meant by the expression "developing flexibility". Some interventions are aimed at helping each adolescent to construct a subjective system which is at one and the same time rich, diversified and articulated. "Exploration" is encouraged. This was the aim of the European "grand tour" of affluent young men in the 18th and 19th centuries. Today, it is one of the aims of methods such as DAPPI (see Guichard \& Dosnon, 1999).

However, the ends of an activity are always defined in terms of certain values. This is why a second line of demarcation differentiates guidance methods: is their final goal to preserve or, on the contrary, to transform the structure of social relations ? These two lines of demarcation appear to be relatively independent. This is why methods in the area of helping the career development of adolescents can be presented in the form of a graphic which contrast them according to these two dimensions (see figure 1).

Insert Figure 1 about here

Figure 1 represents a notion that in the areas of careers education or vocational guidance, the objective of certain activities may be to help adolescents to diversify their identity forms system. For example, they encourage involvement in exploration activities. Other activities may pursue the opposing objective: leading the client to stabilize in a vocational identity form with the aim of following a defined career path. This first dimension (right versus left) is independent of a second one (up versus down). It draws a distinction between methods according to whether their objective (implicit or explicit) is to transform the structure of social relations (e.g.: by defining priority actions) or retaining it (e.g.: by merely meeting the demands of a clientele). Activities which can be considered to be characteristic of the two closest poles are mentioned at the four corners of the figure. For example, the proposed development of flexibility (down versus left) refers on to diversification between identity forms, while generally falling within a perspective of maintenance of the structure of social relations. 
The distinction between identity "frames" and "forms" seems to allow an integration of the different approaches of the "subject" and his/her "subjectivity" as they were described in the human sciences during the 20th century. The identity frames are cognitive schemata. They form a system that constitutes a mental representation of social structure and social categories in our society. One can assume that adolescence is an important time in the formation of this system of cognitive frames, which - very likely - evolves much more slowly in the following periods of life. A subjective identity form constitutes a self creation and representation based on the structure of a given identity frame. In complex societies, any individual "creates" him/herself in different forms according to the context and interactions in which s/he is involved. For this reason, his/her subjectivity may appear as relatively malleable. Such a model increases certainly the complexity of adolescent's vocational counseling. It's main aim cannot only be to help the client find the activities that fit best to the person that he or she is. The aim is also to help him/her to discover and build the subjective system of identity forms in which s/he intends to construct him/herself. As these identity forms refer to social categories (via the cognitive system of identity frames), this is not only a problem of personal development. It raises the question of the society that we want to develop. 


\section{(Tables to be inserted in the text)}

Table 1

"The way that I am". "Own self-image": overall mean scores

Assessment

Group First Second

$\begin{array}{lll}\text { Experimental } & 4.58 & 5.22 \\ \text { Control } & 4.78 & 4.63\end{array}$

Note. To help in reading this table: 4.58 = mean scores assigned by D.A.P.P.I. course participants, to all descriptors, at the time of the first questionnaire.

Table 2

"The way that I imagine the educator sees me". "Social self-image educator": overall mean scores

Assessment

Group First Second

$\begin{array}{lll}\text { Experimental } & 3.96 & 4.99 \\ \text { Control } & 4.36 & 4.35\end{array}$


Adolescents' Identity Frames and Future Projects

(Figure to be inserted in the text)

Figure 1

Ends of Vocational Guidance Methods.

\begin{tabular}{|c|c|c|c|c|}
\hline \multicolumn{2}{|c|}{$\begin{array}{l}\text { identification and } \\
\text { development of abilities } \\
\text { of underachievers } \\
\text { (psychotechnics) }\end{array}$} & \multicolumn{2}{|c|}{$\begin{array}{l}\text { transformation of } \\
\text { the structure of } \\
\text { social relations }\end{array}$} & $\begin{array}{l}\text { encourage } \\
\text { collective } \\
\text { actions }\end{array}$ \\
\hline \multicolumn{5}{|c|}{ target priority groups } \\
\hline $\begin{array}{l}\text { stabilization } \\
\text { in an identity } \\
\text { form }\end{array}$ & $\begin{array}{l}D \\
E \\
C \\
I \\
S \\
I \\
O \\
N\end{array}$ & $\begin{array}{l}\text { help } \\
\text { adolescents } \\
\text { in their } \\
\text { careers } \\
\text { development }\end{array}$ & $\begin{array}{c}E \\
X \\
P \\
L \\
O \\
R \\
A \\
T \\
I \\
O \\
N\end{array}$ & $\begin{array}{l}\text { diversification of } \\
\text { subjective system } \\
\text { of identity forms }\end{array}$ \\
\hline \multicolumn{5}{|c|}{ respond to the demand of a clientele } \\
\hline $\begin{array}{l}\text { encourage the } e \\
\text { of a scholastic } \\
\text { self image }\end{array}$ & nergence & $\begin{array}{l}\text { preserve the } \\
\text { structure of } \\
\text { social relat }\end{array}$ & & $\begin{array}{r}\text { develop individual } \\
\text { flexibility } \\
\text { (employability) }\end{array}$ \\
\hline
\end{tabular}




\section{References}

Bakhtin, M. M. (1981) The dialogic imagination (M. Holquist ed.). Austin: University of Texas Press.

Bandura, A. (1977). Social Learning theory. Englewood Cliffs (New Jersey): Prentice-Hall.

Barsalou, L. (1992). Cognitive Psychology: an overview for cognitive scientists. Hillsdale (New Jersey): Lawrence Erlbaum Associates.

Becker, H. S. (1963). Outsiders. The free Press of Glencoe: Macmillan Publishing. French translation (1985). Paris: Editions A.M. Métailié.

Bourdieu, P. (1984). Distinction: A Social Critique of the Judgment of Taste. Cambridge (Massachussets): Harvard University Press.

Bourdieu, P., \& Wacquant, L. (1992). An Invitation to Reflexive Sociology. Chicago: The University of Chicago Press.

Bruner, J. S., Tagiuri, R. (1954). The perception of people. In Lindsey, G. (ed.): $\underline{\text { Handbook of }}$ social psychology. (vol. 2). Cambridge (Massachussets): Addison-Wesley.

Camilleri, C. \& al. (1990). Les stratégies identitaires. Paris: PUF.

Cattell, R.-B. (1950). Personality: a systematic, theoretical, and factual study. New-York: Mc Graw Hill.

Codol, J.-P. (1975). On the so-called "superior conformity of the self" behaviour: twenty experimental investigations. European Journal of Social Psychology, 5, 390, 457-501.

Doise, W. (1990). Les représentations sociales. In R. Ghiglione, Cl. Bonnet \& J.-F. Richard (éds): Traité de psychologie cognitive (tome 3, pp. 111-172). Paris: Dunod.

Dubar, Cl. (Ed.) (1987). L'autre jeunesse. Lille: PUL.

Dubar, C. (1992). Formes identitaires et socialisation professionnelle. Revue Française de Sociologie, 33, 505-530.

Dubar, C. (1996). La sociologie du travail face à la qualification et à la compétence. Sociologie du Travail, 2, 179-193.

Dubar, C. (1998a). La socialisation. Construction des identités sociales et professionnelles (2ème édition revue). Paris: Armand Colin. 
Dubar, C. (1998b). Identité professionnelle et récits d'insertion. Pour une approche socio-sémantique des constructions identitaires. L'Orientation Scolaire et Professionnelle, 27, 1, 95-104.

Dumora, B. (1990). La dynamique vocationnelle chez l'adolescent de collège: continuité et rupture. L'Orientation Scolaire et Professionnelle, 19, 2, 111-127.

Elias, N. (1987). Die Gesellschaft der Individuen. Francfort/Main: Suhrkamp Verlag.

Elias, N. (1991). La société des individus. Paris: Arthème Fayard.

Erikson, E. (1968). Identity: Youth and crisis. New York: Norton.

Foucault, M. (1984). Le souci de soi (Histoire de la sexualité, tome 3). Paris: Gallimard.

Foucault, M. (1984). L'éthique du souci de soi comme pratique de la liberté. Concordia. Revista internacional de filosofia, 6, 99-116. Repris dans: M. Foucault (1994). Dits et écrits, volume 4, 708-729.

Foucault, M. (1988). Technologies of the self. In P.-H Hutton, H. Gutman \& L.-H. Martin (Eds), Technologies of the Self: a seminar with Michel Foucault (pp. 16-49). Anherst: the University of Massachusetts Press. (French translation (1994), Dits et écrits, tome IV, pp. 783-813).

Foucault, M. (1994). Dits et écrits, 4 volumes. Paris: Gallimard.

Freud, S. (1917). Introductory lectures on Psychonalysys. In Standard Edition (1963, Vol. 15 \& 16). London: Hogarth.

Gilly, M., Lacour, M., \& Meyer, R. (1972). Image propre, images sociales et statut scolaire: étude comparative chez des élèves de CM2. Bulletin de Psychologie, 25, 792-806.

Ginzberg, E., Ginsburg, S., Axelrad, S., \& Herma, J., (1951). Occupational choice: an approach to a general theory. New York: Columbia University Press.

Goffman, E. (1974). Les rites d'interaction. Paris: Editions de Minuit.

Gottfredson, L.S. (1981). Circumscription and compromise: A developmental theory of occupational aspirations. Journal of Counseling Psychology Monograph, 28, 6, $545-579$.

Guichard, J. (1989). Career education in France: new objectives and new methods. British Journal of Guidance and Counselling, 17, $\mathrm{n}^{\circ} 2,166-178$. 
Guichard, J. (1992). Comparative evaluation of several educational methods used in orientation: tools, results and methodological problems. European Journal of Psychology of Education, 7, 1, 73-90.

Guichard, J. (1993). L'école et les représentations d'avenir des adolescents. Paris: PUF.

Guichard, J. (1996). Cultural habitus, school experiences and the formation of future intentions in adolescence. Revista Portuguesa de Psychologia, 31, 9-36.

Guichard, J. (1998). Conceptions de la qualification professionnelle, organisation scolaire et pratiques en orientation. Cahiers Binet-Simon, $\mathrm{n}^{\circ}$ 656, 117-139.

Guichard, J., Devos, P., Bernard, H., Chevalier, G., Devaux, M., Faure, A., Jellab, M., \& Vanesse, V. (1994a). Diversité et similarité des représentations professionnelles d'adolescents scolarisés dans des formations différentes. L'Orientation Scolaire et Professionnelle, 23, 4, 409-437.

Guichard, J., Devos, P., Bernard, H., Chevalier, G., Devaux, M., Faure, A., Jellab, M., \& Vanesse, V. (1994b). Habitus culturels des adolescents et schèmes représentatifs des professions. L'Orientation Scolaire et Professionnelle, 23, 4, 439-464.

Guichard, J., \& Falbierski, E. (1994). Compétences et projets: mots vides ou concepts pertinents pour l'insertion des jeunes en difficulté ? Carriérologie, 5, 3, 131-157.

Guichard, J., \& Cassar, O. (1998). Social fields, habitus, and cognitive schemes. Study stream and the categorisation of occupations. Revue Internationale de Psychologie Sociale, 11, $1,123-145$.

Guichard, J., \& Dosnon, O. (1999). Cognitive and social relevance of psycho-pedagogical methods in guidance. Journal of Career Development, 25, (To be published).

Gysbers, N.C. \& Moore, E.J. (1973). Life career development: A model. Columbia: University of Missouri.

Havighurst, R.J. (1953). Human development and education. White Plains (New York): Longman.

Häyrynen, Y.P. (1995). Le concept de soi: un bien personnel, une norme ou une entité légitime ? L'Orientation Scolaire et Professionnelle, 24, 1, 5-17.

Hogg, M. A., \& Abrams, D. (1988, 1992). Social Identifications. Londres: Routledge. 
Holland, J.L. (1973). Making vocational choices: a theory of careers. Englewoods Cliffs (New Jersey): Prentice-Hall.

Huteau, M. (1982). Les mécanismes psychologiques de l'évolution des attitudes et des préférences vis-à-vis des activités professionnelles. L'Orientation Scolaire et Professionnelle, 11, 2, 107-125.

Jacques, F. (1979). Dialogiques, recherches logiques sur le dialogue. Paris: PUF.

James, W. (1890). Principles of Psychology. New York: Holt.

Jung, C.G. (1926). The structure and dynamics of the psyche. In Collected works (1960, Vol. 8). Princeton: Princeton University Press.

Kelly, G.A. (1955). The psychology of personal constructs. New York: Norton.

Kokosowski, A. (1983). Déterminants socio-scolaires, rationalisations et orientation des lycéens et étudiants. In A. Kokosowski (éd.), Les lycéens face à l'enseignement supérieur. Issy-Les-Moulineaux: EAP, 127-170.

Krumboltz, J.-D. (1979). A social learning theory of career decision making. In A.-M. Mitchell, G.-B. Jones, and J.-D. Krumboltz (éd.): Social learning and career decision making. Cranston (Rhode Island): The Carroll Press.

Laks, B. (1983). Langage et pratiques sociales, étude sociolinguistique d'un groupe d'adolescents. Actes de la Recherche en Sciences Sociales, 46, 73-97.

Law, B. (1981). Community Interaction: a "Mid-Range Focus for Theories of Career Development in Young Adults. British Journal of Guidance and Counselling, 9, 2, 142-158.

Law, B. (1996). A Career learning theory. In A.-G. Watts, B. Law, J. Killeen, J.-M. Kidd \& R. Hawthorn (éds.), Rethinking Careers Education and Guidance, Theory, Policy and Practice (pp. 46-71). Londres: Routledge.

Mead, G.H. (1934). Mind, self and society. Chicago (Ill.): University of Chicago Press.

Meyer, R. (1986-1987). Image de soi et statut scolaire. Influence des déterminants familiaux et scolaires chez des élèves du cours moyen. Bulletin de Psychologie, 49, 382, 933-942.

Minsky, M. (1975). A framework for representing knowledge. In P.-H. Winston (ed.), The Psychology of Computer Vision. New York: MacGraw-Hill. 
Monteil, J-.M. (1988). Comparaison sociale. Stratégies individuelles et médiations socio-cognitives. Un effet de différenciations comportementales dans le champ scolaire. European Journal of Psychology of Education, 3, 1, 3-18.

Monteil, J-.M. (1990). Eduquer et former: perspectives psycho-sociales. Grenoble: Presses de l'Université de Grenoble.

Motola, M., Sinisalo, P. \& Guichard, J. (1998). Social habitus and future plans - A comparison of adolescent future-projects in Finland and France. In J.-E. Nurmi (Ed.), Adolescence, culture and conflicts: growing up in contemporary Europe (pp. 43-73). New York: Garland Publishing.

Nizet, J., \& Hiernaux J.-P. (1984). Violence et ennui. Paris: PUF.

Nurmi, J.-E. (1991). How do adolescents see their future ? A review of the development of future orientation and planning. Developmental Review, 11, 1-59.

Nurmi, J.-E. (1997). Self definition and mental health during adolescence and young adulthood. In J. Schulenberg, J. Maggs, and K. Hurrelmann (eds), Health risks and developmental trajectories during adolescence (pp. 395-419). Cambridge (Massachussets): Harvard University Press.

Parsons, F. (1909). Choosing a vocation. Boston: Houghton Mifflin.

Reuchlin, M. (1978). Processus vicariants et différences individuelles. Journal de psychologie normale et pathologique, $75,138-145$.

Reuchlin, M. (1997). La Psychologie différentielle. (nouvelle édition entièrement refondue). Paris: PUF, Le Psychologue.

Rogers, C.-R. (1961). On becoming a person: a therapist's wiew of psychotherapy. Boston: Houghton Miflin.

Roe, A. (1956). The Psychology of Occupations. New York: Wiley.

Sartre, J. P. (1952). Saint Genet, comédien et martyr. Paris: Gallimard.

Schank, R. C., Abelson, R. P. (1977). Scripts, plans, goals and understanding. Hillsdale (New Jersey): Lawrence Erlbaum.

Schank, R. C. (1995). De la mémoire humaine à la mémoire artificielle. La Recherche, 26, 273, $150-155$. 
Super, D.-E. (1957). The Psychology of Careers: an Introduction to Vocational Development. New York: Harper.

Super, D.-E. (1984). Career and life development. In D. Brown, L. Brooks, \& al. (Eds.), Career and life development (pp. 1992-234). San Francisco: Jossey-Bass.

Taboada-Leonetti, I. (1990). Stratégies identitaires et minorités: le point de vue du sociologue. In C. Camilleri, \& al., Les stratégies identitaires (pp. 43-83). Paris: PUF.

Tajfel, H. (ed.) (1982). Social Identity and Intergroup Relations. Cambridge: Cambridge University Press.

Tap, P. (éd.) (1980). Identité individuelle et personnalisation. Toulouse: Privat.

Touraine, A. (1955). La qualification du travail: histoire d'une notion. Journal de psychologie normale et pathologique, $13,27-76$.

Turner, J.-C. (1985). Social categorisation and the self concept: a social cognitive theory of group behaviour. In E.-J. Lawler (ed.): Advances in Group Processes: Theory and

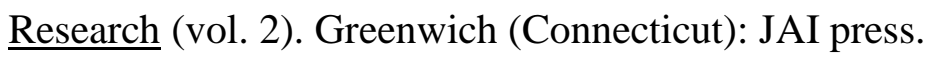

Vondracek, F.-W., Lerner, R.-M., Schulenberg J.-E. (1986). Career development: a life span developmental approach. Hillsdale (New Jersey): Lawrence Erlbaum.

Wallon, H. (1934). Les origines du caractère chez l'enfant. Les préludes du sentiment de personnalité. Paris: Presses Universitaires de France.

Wertsch, L.-V. (1990). The voice of rationality in a sociocultural approach to mind. In L.-C Moll (ed.): Vygotsky and Education. Instructional Implications and Applications of Sociohistorical Psychology. New York: Cambridge University Press.

Willis, P. (1977). Learning to labour: How Working-Class Kids Get Working-Class Jobs. New-York: Columbia University Press.

Willis, P. (1978). L'école des ouvriers. Actes de la Recherche en Sciences Sociales, 24, 50-61.

Zavalloni, M., \& Louis-Guérin, C. (1984). Identité sociale et introduction à l'égo-écologie. Montréal: P.U.M. 